\title{
Research on the Factors Affecting China's Export Trade of High-tech Products to Southeast Asian Countries
}

\author{
Xinjie Luo \\ School of Economy and Management \\ Beijing Jiaotong University \\ Beijing, China
}

\author{
Yongchao Sun \\ Business School \\ The University of Leeds \\ Leeds, the UK
}

\begin{abstract}
China's high-tech industry has flourished in recent years, and the export trade volume of high-tech products has also increased year by year. As a major destination for China's high-tech products exports, Southeast Asian countries have become the new engine for the development of this industry. Therefore, it is very important to study the status quo and problems of high-tech products trade between China and Southeast Asian countries. It can not only promote the expansion of bilateral trade in high-tech products, but also accelerate the development of bilateral high-tech industries. This paper selects the panel data from 2006 to 2015 , and uses the extended gravity model to empirically analyze the main factors affecting the export of China's high-tech products to Southeast Asian countries, and proposes relevant suggestions based on the analysis results.
\end{abstract}

Keywords-high-tech products; southeast Asian countries; gravity model

\section{INTRODUCTION}

\section{A. Research Purposes}

Based on China's export flows of high-tech products to Southeast Asian countries and other relevant data, this paper explores the factors that promote or limit the export of hightech products from China through the expansion of the gravity model so that corresponding measures can be taken to expand the scale of China's exports to Southeast Asian countries in high-tech fields and promote the development of China's high-tech industries.

Not only can it improve the trade structure of exports, but it can also effectively drive the rapid development of China's economy.

The key questions in this paper are as follows. First, what factors are affecting China's high-tech products exporting to Southeast Asian countries? Second, what is the target markets based on the potential export value of high-tech products?

\section{B. Research Background and Current Status of High-tech Industry}

In recent years, scientific and technological progress has become an important source of economic development, and the development of high-knowledge industries represented by high-tech industries has become the fundamental driving force for economic growth. [1] In the past ten years, China's high-tech industry has developed rapidly and has produced a huge driving force for economic development. In 2017, China's high-tech industry added value accounted for $30 \%$ of the world's added value, accounting for $16 \%$ of the manufacturing added value, and China became the largest high-tech industry country in the world. China's R\&D expenditures have also increased steadily, accounting for $2.12 \%$ of GDP, surpassing the EU's $1.96 \%$ for four consecutive years. China's high-tech enterprises' research expenditures reached 540 billion yuan in 2017 , accounting for about $44 \%$ of national expenditures, an increase of about $20 \%$, which is about twice the national growth rate. At the same time, among the world's top 500 enterprises, China's high-tech enterprises number has reached 11 .

In the trade field of high-tech industries, according to the website data of the Ministry of Commerce, the proportion of high-tech products trade accounts for a growing proportion of goods trade, of which electronic equipment products of communication equipment occupy an absolute share [2]. In the first half of 2018, China's exports of high-tech products reached 343.3 billion dollars, an increase of $18 \%$ year-onyear. The total export volume exceeds the sum of Germany, Japan and the United States, ranking first in the world. At the same time, trade surplus remains at 50 billion dollars. With the "Belt and Road" strategy proposed, China's export of high-tech products has become an important force in the development of China's foreign trade.

Developing countries have large development space in the high-tech field, and need to establish funds, raise labor costs and use scientific and effective management methods [3]. Therefore, how to promote the optimization and upgrading of high-tech industries, how to rationally lay out the industrial structure, and make the high-tech industry 
better drive economic development has become a difficult problem to break through [4].

Southeast Asian countries are one of China's most important trading partners. ASEAN ranks third in China's high-tech product export region. In 2003, China officially established a strategic partnership with ASEAN. The scale of bilateral trade in high-tech fields has expanded year by year. Therefore, it is of practical significance to select the region for research. (See "Table I")

TABLE I. ChINA'S High-TECH PRODUCTS TRADE TO SOUTHEAST ASIAN COUNTRIES FROM 2015 TO 2006

\begin{tabular}{|l|l|l|l|l|l|}
\hline & \multicolumn{1}{|c|}{ LS } & \multicolumn{1}{|c|}{ OT } & CC & ET & CIM \\
\hline $\mathbf{2 0 0 6}$ & 5.68 & 16.99 & 137.92 & 58.40 & 2.95 \\
\hline $\mathbf{2 0 0 7}$ & 8.69 & 18.93 & 175.37 & 70.60 & 4.81 \\
\hline $\mathbf{2 0 0 8}$ & 10.82 & 23.51 & 190.16 & 77.80 & 6.47 \\
\hline $\mathbf{2 0 0 9}$ & 9.15 & 20.67 & 184.62 & 74.13 & 6.04 \\
\hline $\mathbf{2 0 1 0}$ & 11.21 & 29.89 & 205.61 & 88.60 & 10.49 \\
\hline $\mathbf{2 0 1 1}$ & 14.38 & 37.71 & 217.08 & 85.25 & 11.68 \\
\hline $\mathbf{2 0 1 2}$ & 13.51 & 45.98 & 244.81 & 94.88 & 14.39 \\
\hline $\mathbf{2 0 1 3}$ & 14.99 & 46.39 & 270.61 & 121.06 & 18.35 \\
\hline $\mathbf{2 0 1 4}$ & 16.49 & 45.80 & 294.84 & 135.33 & 22.34 \\
\hline $\mathbf{2 0 1 5}$ & 17.80 & 41.34 & 306.84 & 155.82 & 22.50 \\
\hline
\end{tabular}

${ }^{\text {a. }}$ LS, OT, CC, ET and CIM respectively refer to life sciences, optical technology, computer and communication, electronic technology and computer integrated manufacturing. The Unit is
$\$ 100$ million.

\section{RESEARCH ON THE INFLUENCING FACTORS OF CHINA'S HIGH-TECH INDUSTRY}

\section{A. Definition of High-tech Products}

In 1999, the Ministry of Science and Technology and other relevant departments jointly released the 2000 edition of China's High-tech Products Export Catalogue which divided high-tech products into nine categories: biotechnology, life science technology, optoelectronic technology, electronic technology, computer integrated manufacturing technology, materials technology, aerospace technology, computer and communication technology and other technologies. According to the principle of data accessibility, this paper selects five major categories of life science, optoelectronic technology, computer and communication technology, electronic technology and computer integrated manufacturing technology as representatives of high-tech products [5].

\section{B. Selection and Setting of Gravity Model}

The gravity model is an economic model proposed by Tinbergen (1962) [7] and Poyhonen (1963) [8] based on Newton's universal gravitation formula and extended and extended in the economic field. At first, it was used to study the volume of international trade; afterwards, scholars continue to expand the gravitational model. The current trade gravity model is one of the commonly used models in the field of trade influencing factors. Therefore, this paper uses the trade gravity model to conduct research based on previous studies. The basic logarithmic form of the gravity model of trade is:

$$
\ln X_{i j}=A_{0}+A_{l} \ln Y_{i} Y_{j}+A_{2} \ln D_{i j}+u_{0}
$$

In the model, $X i j$ represents the export value of exporting country $i$ to importing country $j$. Yi represents the GDP of exporting country $i$. $Y j$ represents the GDP of importing country $j$. Dij represents the distance between the capitals of the two countries. $A O A 1$ and $A 2$ are the regression coefficient, and $u 0$ standards random error [3].

According to the actual research in this paper, in order to explore the impact of intra-industry trade on China's hightech products exports, this paper adds the difference of the GDP per capita between both countries as an explanatory variable, expressed by IITce. R\&D expenditure is closely related to the development of high-tech industries. Therefore, the proportion of China's R\&D input in GDP is cited as a measure of the development level of China's science and technology, which is expressed by SHct. Therefore, the final form of the gravity model is as follows.

$\ln$ EXPce $=A 0+A 1 \ln$ GDPctGDPet $+A 2 \ln D c e+$ A3InIITce + A4OPPENNESSet + A5SHct + uce

EXPce represents China`s exports amount to Southeast Asian countries, A1-5 is the regression coefficient and uce is the standard random error.

\section{Samples and Data Sources}

This paper selected the trade flow of China's exports of high-tech products to Southeast Asian countries from 2006 to 2015 to build panel data. After Deleting data for East Timor, this paper finally selected 10 sample countries: Vietnam, Laos, Thailand, Malaysia, Singapore, Philippines, Brunei, Indonesia, Myanmar and Cambodia. The data was compiled from the UNCOMTRADE database. At the same time, the GDP and GDP per capita of China and 11 sample countries in southeast of Asia were all obtained from the World Bank. The distance data comes from APP DISTANCE. And the trade dependence of Southeast Asian countries was calculated by World Bank data. The data of China's science and technology development level came from the World Bank.

\section{Empirical Analysis of Gravity Model}

In this paper, econometric software Eviews8.0 is used to construct panel data and conduct ADF unit root test. The variables $\operatorname{lnGDP}$ ctGDPet, IITce, OPPENESSet are all stationary series at a significant level of 1 percent, and SHct is stationary series at a significant level of 5 percent, so that it is not necessary to do differential work on variables. Therefore, the data of fixed effect model and random effect model are respectively constructed for Hausman test, and the result is: Prob. $=0.0013<0.05$. The null hypothesis is not true so the random effects model can't be used. However, since the panel contains the distance term that does not change with time, and the fixed effect model is not used, the mixed model is adopted in this paper. Moreover, in order to avoid the influence of heteroscedasticity and autocorrelation on the results as far as possible, the "backward method" is adopted to gradually carry out GLS (generalized least square) regression for panel data. The regression results are as follows: (see "Table II") 
TABLE II RESULTS OF REGRESSION MODEL

\begin{tabular}{|c|c|c|}
\hline Project & $\begin{array}{c}\text { Basic } \\
\text { Regression } \\
\text { Equation }\end{array}$ & $\begin{array}{c}\text { Extended } \\
\text { Regression } \\
\text { Equation }\end{array}$ \\
\hline $\boldsymbol{c}$ & -41.56441 \\
$(-14.68) * * *$ & $\begin{array}{c}-35.88550 \\
(-17.00)\end{array} * * *$ \\
\hline InGDPctGDPet & 0.941919 \\
& $(20.10) * * *$ & 0.920755 \\
$(21.72)$ & $* * *$ \\
\hline IITce & - & -0.187650 \\
& & $(-3.27)^{* * *}$ \\
\hline Dce & -0.870634 & -1.180106 \\
& $(-2.75) * * *$ & $(-4.87)^{* * *}$ \\
\hline OPPENNESSet & - & 0.005674 \\
& & $(8.57) * * *$ \\
\hline SHct & - & 0.006660 \\
& & $(2.58) * *$ \\
\hline Adjusted R2 & 0.825276 & 0.920936 \\
\hline
\end{tabular}

The values in parentheses are $\mathrm{t}$ values. $* * *, * *$, and $*$ indicate significant at the $1 \%$, $5 \%$, and $10 \%$ levels.

From the regression results, the selected variables passed the test at different significant levels. It can be seen that the selected variables have a significant impact on the export of high-tech products, and by affecting the export of high-tech products it will also counteract the development of China's high-tech industries and have a significant impact on the development of China's high-tech industries. According to the results, the final regression model is:

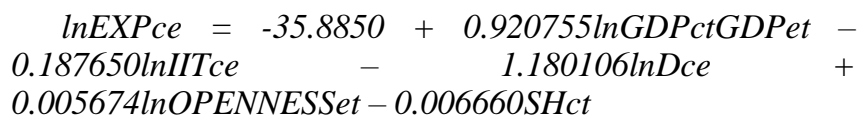

The regression explanations are as follow:

- The coefficient of China's scientific and technological development level is positive, indicating that the proportion of China`s R\&D investment in GDP is directly proportional to the export volume of hightech products. It can be explained that the higher the proportion of China`s R\&D investment in GDP, the greater the export volume of high-tech products. The export of high-tech products is conducive to stimulating demand, promoting the improvement of production efficiency and the continuous improvement of the industrial chain, and thus contributing to the continuous development of hightech industry.

- From the perspective of the distance variable coefficient, the distance has the greatest negative impact on product exports. In the process of exporting products, it is necessary to adopt comprehensive transportation methods. Therefore, providing diversified transportation modes, reducing transportation costs will promote the export of hightech products, and then promote high-tech industry.

- The level of trade openness in Southeast Asian countries also has a significant impact on exports, which in turn affects the development of high-tech industry. If cooperation opportunities were created to seek trade cooperation, actively carry out economic and trade cooperation between China and ASEAN, and promote the vigorous and orderly development of bilateral trade, it will be conducive to the rising demand for high-tech products in China, and thus promote the continuous innovation of high-tech industry.

\section{FORECAST OF EXPORT POTENTIAL}

Based on empirical analysis results, and taking the 2015 data as an example, the export potential of high-tech products from China and Southeast Asian countries was calculated.

\section{Potential value $=$ actual value/predicted value}

If the potential value is greater than 1 , it is called excessive trade. If the potential value is less than 1 , it is called insufficient trade [6].

As shown in "Table II", in the field of life sciences, the "over-trade" country is only Singapore. In the field of optoelectronic technology, the "over-trade" countries are Singapore, Cambodia, Malaysia, and Vietnam. In the field of computer and communication technology, the only "overtrade" country is Singapore. In the field of electronic technology, the countries with "over-trade" are Singapore and Vietnam. In the field of computer integrated manufacturing technology, "under-trade" countries include Singapore, Indonesia, Thailand, Malaysia, Philippines and Vietnam. (See "Table III")

TABLE III. CHINA 'S EXPORT POTENTIAL OF High-TECH PRODUCTS TO SOUTHEAST ASIAN COUNTRIES

\begin{tabular}{|c|c|c|c|c|c|}
\hline & LS & OT & CC & ET & CIM \\
\hline Indonesia & 0.33 & 0.48 & 0.23 & 0.38 & 1.50 \\
\hline Myanmar & 0.60 & 0.88 & 0.41 & 0.68 & 0.71 \\
\hline Singapore & 1.62 & 2.45 & 1.15 & 1.92 & 3.49 \\
\hline Cambodia & 0.83 & 1.20 & 0.55 & 0.91 & 0.29 \\
\hline Thailand & 0.38 & 0.55 & 0.26 & 0.43 & 1.68 \\
\hline Brunei & 0.63 & 0.92 & 0.42 & 0.70 & 0.11 \\
\hline Malaysia & 0.76 & 1.09 & 0.51 & 0.84 & 2.54 \\
\hline Laos & 0.26 & 0.38 & 0.17 & 0.29 & 0.10 \\
\hline Philippines & 0.34 & 0.50 & 0.24 & 0.40 & 1.35 \\
\hline Vietnam & 0.99 & 1.47 & 0.70 & 1.17 & 1.50 \\
\hline
\end{tabular}

LS, OT, CC, ET and CIM respectively refer to life sciences, optical technology, computer and communication, electronic technology and computer integrated manufacturing

\section{CONCLUSION}

\section{A. Increasing Investment in $R \& D$ Funding}

From the results of empirical analysis, it can be known that the investment in R\&D funds has a significant impact on the development of China's high-tech industry. If the government keeps increasing $\mathrm{R} \& \mathrm{D}$ through various means such as fiscal, finance and tax incentives, increasing the intensity of high-tech investment, strengthening the transformation, promotion and application of results with independent intellectual property rights to improve China's scientific and technological level and independent research and development level, promoting the transfer of production from labor-intensive products to high value-added, high-tech 
and knowledge-intensive products, it will be conducive to the development of China's high-tech industry.

\section{B. Strengthening Infrastructure Construction}

In the empirical results, the distance is an obstacle to the export of high-tech products, which in turn will hinder the development of high-tech industries. Therefore, strengthening infrastructure construction, providing diversified transportation modes, improving the speed of transportation, reducing transportation costs, are conducive to reducing the production costs of high-tech industries, and thus better promoting the optimization and upgrading of the industry.

\section{Creating Opportunities to Strengthen Cooperation}

It can be seen from the regression results that the trade dependence of Southeast Asian countries has a significant impact on the development of China's high-tech industries. Innovation activities are produced by both the supply side and the demand side. [9] Therefore, expanding cooperation will help promote the development of the industry. Since the establishment of the China-ASEAN Free Trade Area, bilateral economic trade and scientific and technological exchanges have developed rapidly. Taking advantage of the resource advantages of the Free Trade Zone, strengthening mutual investment and technical cooperation based on the "Belt and Road" strategy, and targeted cooperation in the high-tech field will promote the continuous upgrading of China's high-tech industry.

\section{Focusing on Digging for Potential Markets}

According to the trade potential index, focusing on tapping the market with great potential, promoting the development of trade, and then promoting the sound and rapid development of the economy through trade will have a huge pulling effect on the development of China's high-tech industry.

\section{REFERENCES}

[1] C. Cui, "Thoughts on the Status Quo and Function of High-tech Industry Development," in Docking Beijing and Tianjin — Laying the foundation for the new era, 2018, pp. 206-212.

[2] D. Zhang and X. Cui, "Research on the Open Development and Industrial Security of China's High-tech Industry," International Trade, no. 12, pp. 19-22, 2018

[3] B. Cheng and Y. Tian, "Chinese wooden furniture export dependence analysis," Journal of International Business, no. 1, pp. 65-70, 2012.

[4] C. Fan and Y. Zhao, "Analysis on the Evolution of Innovation Efficiency of High-tech Industry and Its Influencing Factors Taking Zhongguancun Science and Technology Park as an Example," Modern Management Science, No. 1, pp. 6-8, 2019.

[5] H. Hu, "Analysis of Factors Affecting the Growth of Cross-Strait High-Tech Products Trade - Based on Modified CMS Model," International Economic and Trade Exploration, no. 4, pp. 13-23, 2017.

[6] D. Wu, "East Asian Bilateral Import Trade Flows and Potential: An Empirical Study Based on Trade Gravity Model," International Trade Issues, no. 5, pp. 32-36, 2008

[7] Tinbergen, J, "Shaping the World Economy: Suggestions for an International Economic Policy," The Twentieth Century Fund, pp.37 39,1962 .
[8] Poyhonen, P, "A Tentative Model For the Flows of Trade Between Countries," Weltwirtschatftliches A rchiv, no. 90, pp. 3-9, 1963

[9] Charles Edquist, Leif Hommen, "Systems of Innovation: Theory and Policy for the Demand Side," Technology in Society, on. 21, pp. 63 79, 1999

[10] Peter Gustafsson, Pual Segerstrom, "North-South trade with increasing product variety," Journal of Development Economics, no. 92, pp. 97-106, 2009 